\title{
Mediality: the cultural-symbolic sphere of social practice
}

\author{
Thomas A. Bauer \\ https://orcid.org/0000-0003-0318-539X \\ I - University of Vienna. \\ Vienna, Austria.
}

\begin{abstract}
At least since the practical complexity of media landscapes is growing, the theoretical complexity of media communication has to be widened (horizon and frame) and deepened (focus) - especially when fulfilling the mission and the quality of science: generating complexity on a level of logical theory towards a subject that is not an object by itself but a culturally programmed metaphor of description: communication, culture, society etc. The complexity of communication, media or society is not a character of those constructs themselves but a complexity of thinking, in practice hopefully reduced, in theory hopefully produced. Facing communication (more) as a cultural performance of humanness and of social practice and facing media (more hermeneutically than technically) demands to conceptualize those constructs as models of knowledge, as culturally programs in search of mindful meaning and meaningful relevance of social /societal life. Therefore, there is need of a shifting paradigm from functional, objectivist concepts to hermeneutically open concepts - not only, but also to generate a wider frame of analysis and interpretation of social and cultural change referred through the mediality character of communication and society. So called social media are not new media but show the possibility as well the challenge and chance of change of media orders. Of course, that demands other (new) competence concepts of social practice.
\end{abstract}

Keywords: mediality; mediology; critical theory; media competence; contextual concept.

Resumo: Midialidade: a esfera cultural-simbólica da prática social Considerado o aumento da complexidade prática das paisagens midiáticas, 
a complexidade teórica da comunicação midiática tem que ser ampliada (no horizonte e na moldura) e aprofundada (no foco) - especialmente para cumprir a missão de aprimorar a qualidade dessa ciência: gerando complexidade em um nível de teoria lógica para um assunto que não é um objeto em si mesmo, mas uma metáfora de descrição culturalmente programada: comunicação, cultura, sociedade, etc. A complexidade da comunicação, da mídia ou da sociedade não é um caráter desses construtos em si, mas uma complexidade de pensamento que, na prática, espera-se que seja reduzida, ao passo que na teoria seja produzida. Encarar (mais) a comunicação como uma performance cultural da humanidade e da prática social, e encarar a mídia (mais hermeneuticamente do que tecnicamente) requer conceituar aqueles construtos como modelos de conhecimento, como programas que culturalmente buscam significados conscientes e relevância significativa da vida social. Portanto, é necessário que haja uma mudança de paradigmas de conceitos funcionais e objetivistas para outros que sejam hermeneuticamente abertos - não apenas, mas também para gerar um quadro mais amplo de análise e interpretação das mudanças sociais e culturais, referidas pelo caráter de midialidade da comunicação e da sociedade. As chamadas mídias sociais não são novas mídias, mas mostram tanto a possibilidade, quanto o desafio e a oportunidade de mudança de ordens da mídia. Sem dúvidas, isso requer outros (novos) conceitos de competência da prática social.

Palavras-chave: midialidade; midialogia; teoria crítica; competência da mídia; contexto conceitual.

\section{Mediology: shifting the paradigms of theoretical logics. Observing media as frame of reference of social construction of relevance of reality.}

The more complex the media landscapes are getting; the more media science is challenged to widen (the frame) and to deepen (the focus) the logical sphere of complexity. A scientifically acting theory is not just an ordering system of what we think communication, media, society or culture is, could be or should be: it needs a logical reference (format) of observation, of conceptualisation, of definition, of determination, and of problematization, in order to be able to match a level of complexity that goes farer then the complexity-feeling of everyday observation. While the everyday observation is interested in reducing the complexity (using causal or even mechanical models of imagination), the scientific observation is expected to widen the frame (options) of complexity until the point of getting to recognize that there was even more to know, what we might still not be able to explain, to order, to signify or to classify. 
The constructivist thinking teaches us that complexity is not a character of the constructs we observe (like communication, society, culture, religion, family, media etc.), its rather the complexity of observation, by which we objectify contexts of acting and living (cf. SCHMIDT, 2003; SCHÜTZ; LUCKMANN, 2003; BAUER, 2014). Consequently, and simply to say: we cannot resolve problems with models of thinking (objectivation) by which we are creating or evoking the problems. A logical frame enables to get aware of a logical focus and perspective, which could be socio-logical, psycho-logical, or as well anthropological, philosophical or eco-logical one.

In that frame of thinking it makes logical sense to widen the scope and to deepen the focus theorizing media not just as tools, channels, platforms, or means of and for communication, and not to reduce the term media to indicate by this unique media (classical or new) and not to structurally separate the term from communication. Facing the philosophical / logical complexity of the media-term, my plaidoyer goes for a hermeneutical turn, based on constructivist approach to understand why we understand in the way we do what we think to understand (cf. BAUER, 2014; GADAMER, 1972; SCHMIDT 2003). The ontological level of media is not (just) the technology, is not (just) the logic of organization, not (just) the logic of economy - kind of unique media ontology (cf. LESCHKE, 1972), but is rather more to explore the options of constructing reality and to social-mutually indicate the relevance of the normative forces of reality. So, it is mind-based inter-activity of observing communication mediatising communication as well as communicating the media sphere.

On a practical and empirical level, the relation of communication and media happens in mode (modus operandi) of functionality and causality: media perform communication and social interaction as communication and interaction happen because of media-activity. On a theory-logical level the relation of communication and media is hermeneutically interpretative mediality is the performative sphere of communication as communication is the generative character of mediality. The ontology of media is inscribed in communication as communication is the matter of media. Media, hermeneutically determined, is the sphere of social acting and observing with and to each another, is a socio-logically / culture-logically (and because of that: media-logically) comprehensible interrelation of societally mutually engaged reference ( $c f$. GADAMER, 1972; KURT, 2004; BAUER, 2014; BURS, 2019). Interpreting the media sphere on such constructivist level mediating 
the constructs of communication, society and culture to each other enables to set up a mediological interpretation of society with the same consequences for any (interpretative/qualitative) analysis as it theoretically is doable and (especially) in frame of systems theory already done, when communication of society gets analysed as a model of society of communication (cf. LUHMANN, 1984; BECKER, 2005) - all that opens a theoretical perspective of the mediality of the society. To bring the idea down to earth: any media research always is social/societal research as social/societal research in same time is research on the mediality status of the society: competence, literacy, quality, impact inclusions.

Considering communication, as well media communication scientifically, as a term that mirrors (frames, refers) social and societal practice, we are using a logical model of sociability in an constructivist way of thinking: society is as we communicate it. That demands to understand the (order of the) society or media by understanding the social (cultural) logic of communication, knowing that the term communication by itself is a metaphor of description contextualizing social action and observation by a concentrate (cf. BAUER, 2014, p. 33).

Any society organizing its status and its development is structurally depending from its interaction and communication system, culturally from its communication quality, and generally from its orders of social practice. Or even better to say: a society is, what its communication is like. The grade of its sociality depends from its cultural level of its sociability competence (BAUER, 2011a, p. 499). In a media-organized society the interaction and communication structure - that means at least mutual attention, traffic, connections, topics etc. - follows prima vista the technical and aesthetical logics, the attractions, the facilities and possibilities but also the limitations, options, challenges, and chances of communication through its mediatized organization and its medialized character (cf. HEPP, 2008; BAUER, 2014, p. 327). In any case, though it is often said that media reduces the complexity of societal communication (cf. LUHMANN, 1968), on the other hand also it gets evident that in a media environment the society and its self-interpretation becomes more complex through this mode of communication - and interaction structure - in manifold perspectives: the increasing amount of information, the variety of aspects, evaluations, opinions and options coming up to public sphere overdrive the capacities of processing of social communication. In order to feel or to realize oneself responsibly as a relevant part or partner within a communication process, one must overlook its social 
space (frame), its relational structures, its options of meaning and relevance and last but not least its contingence of sense. The reference to a culturally defined social framework might help to come clear with orientation.

There is obviously a structural change ongoing in media. Especially since media technology has entered the digital age, not only the modes of production, but much more patterns and attitudes of consumption have changed the traditional ontology of media communication. The key character concerns the role of the consumer now becoming a user - often appealed as prod-user, what means: the industrial fragmentation of roles as a producer and a consumer has overcome, the interaction now happens not any more between producer and consumer, but between user and user. This phenomenon - social convergence - is the social dimension of the technical convergence. The former producer professionalism and the appropriate consumer skills have been fallen in one model of use: taking and giving within a generalized and socially shared model of competence, which is a mutually supposed expectation of trust.

This convergence can be estimated as a horizontalization of a formerly hierarchically ordered relation of trust. A model of dependence (for example: journalism quality - audience media competence) has changed into a model of interdependence of media literacy, which has (to) become the competence motif of a civil society (cf. BAUER, 2011; 2014).

The emergence of social-media-communication (many-to-many media interaction) might be seen as one of the areas of media change, enabling social networks or casual communities and giving them opportunity to establish and to structure open systems of publicity, which by far are not, what the concepts of public sphere think to observe, but portraying a new mode of system of communicative trust. If this, trust (LUHMANN, 1968) is taken as the core principle of what publicity (public sphere) is thought to be - which in any case is a normative concept for any structurally public social communication - and if the perception is right that social media configurations are a matter of (spontaneous and casual) trust, then social media communication is about figuring out new relations of trust beyond of any institutionalization of it. A relation of trust within a media environment of communication must rely on and must engage with the medial performance of communication.

When talking about media change the question arises: what is the theoretical concept understanding media as a societal sphere, and what is or could 
be accepted as a theoretical legitimacy to build a concept of media shaping the societal contexts of personal life? (cf. BURS, 2019). It is somehow selfevident that a structural theory of media just focusing to the technical or even aesthetical materiality of media can not be enough framing a mediological description of society. Media in such an theoretical context must be taken as a hermeneutical term contextualizing the terms of change, media, culture and society: so then not just the media are changing, what is changing is the cultural sphere, the meaning (the observation) of (conditions and valuation of) social practice (cf. HEPP, 2004; 2011; BAUER, 2014). When we are talking about media in such a context, we should - so the epistemologically well based advice of Cultural Studies ( $c f$. HALL, 1980) - not just talk about the structurally given facts but rather about the contexts, in which it gets the significance it has, and which always is meant additionally, but hardly respected in analyses. Not to mention the worlds of construction in relation to them it makes logical sense to face up to the questions of value to be focused on in educational contexts. Media is becoming to what it is and how we understand it through the way as we use or we think we should use it as a reference of and for social interaction and communication as well for societal exchange. The culture of usage predominately is determined by the specific and personally relevant contexts of living of people.

That is, what mediology aims to be: is to be understood as a broad frame of scientification the contextual observation of society, culture and mediatized social relation (practice). In that sense mediology is not a theory of media (structures, systems, organization) but a theory-logical observation of use of media related to the circumstances and contexts of individual and social life. Mediology is not a structural theory but rather cultural hermeneutics of everyday social practice ( $c f$. BAUER, 2014, p. 331). Behind that approach there is a clear motivation: it is the logic of human and human capability that matters, not the logic of technical abilities of systems. In that sense a theory of media owing the logics of media as a socio-cultural sphere (passage) of social practice (mediology) is not just a theory explaining, ordering, classifying and problematizing the structures (systems of hardware and software), but more the theory-logical observation of social use.

\section{The logical tentativeness of objectivism. Concepts theorizing a construct of observation}

Having said all that so shortened, of course, that aims to be a critical assessment of traditional and conventional streams of theoretical explanations 
of the interrelation of media, communication, society and social culture. Saying, a cultural, human and social theory perspective of media communication focuses on the interrelation of observation and action and finds its theoretical paradigm in the concept of signification (cf. HALL, 1989; 1999). Both, observation and action - better to say: observation as an action and action as an observation - construct significations, which get generalized through and as symbolic interaction ( $c f$. MEAD, 1934; HERBERT BLUMER, 1973). The exchange of signification realized in the way of relating action and observation to codes, within a cultural programming development creates generalized configurations of meaning. Culture then is the social interactive and communicative environment to archive those configurations of meaning construction in structures of symbolic and ritual interaction to be used as statement of commitment or as a reference of control for social compliance in case of need. Any style of life is observable as an habitual expression of such commitment and compliance, and that is the reason why it makes sense, when the concept of Cultural Studies observe culture as any "whole way of life" (WILLIAMS, 1958).

Media then, taken as the distinctive factor of differentiation of social communication models, in this technical contextualization of observation of all the process phenomena - logically not surprising - must be seen as mediating (mediatizing) source of generation, creation of those processes, as instruments through which societal communication can be kept in institutional order: all basic social institutes (politics, economy, education, law, cultural rituals of sociability and social conversation) take benefit from such kind of interpretation and configuration of mass media communication. The constellation of social communication in terms of production and consumption follows the industrial principle of taylorization of work. Better to say: the distinction and separation of an integrated process-system in two domains as production and consumption portrays an industrial ideology as a constructive umbrella (Überbau) and as such it tends to generalize a model of organization of success on an economical level by means of technology. What is relevant to say here in the context of the attempt to re-conceptualize an integrated model of competence, is: obviously within this industrial interpretation of media communication even the media educational programs follow this ideology of distinguishable sectors of communication (and media) competence and demand from audience a critical consumption, while from (so called) communicator organizations quality and professionalism. Within 
a taylorized structure of social communication such a concept may make practical sense, but theoretically getting emancipated from and free of such functional conceptualizations of media communication, the concept of competence theoretically is to be used as code for public good - and further of public value - within the description of media communication as the social practice of constituting the society itself in the model of communication in a medialized environment (cf. BAUER, 2008, p. 137; BAUER, 2010).

The functional paradigm within this constellation of perspectives follows the notion of a causality in objective systems on connectivity of observation or action - expressed in logical formation systems like mathematics or techniques (cf. WEBER, 1997). If communication is understood as a concept of acting (and not as a concept of observation, which would be the alternative (cf. MITTERER, 2001; SCHMIDT, 2003; BAUER, 2011; BAUER, 2014, p. 44), then it should not be a surprise

- that media is addressed as the generative (causal) source of influence, as a dispositive of power and influence (FOUCAULT, 1974), and not as the technical environment of social communication of masses;

- that the interest of analytical observation is not directed to the overall cultural and social phenomenon (which would be mediality or mediatisation of social practice (cf. BAUER, 2008; KROTZ, 2001; 2008) but to the unique media as an instrumental item in the middle of systems of distribution of power, of chances of social participation, of news, of commercial and other goods;

- $\quad$ and that media theoretically are denunciated just as stages of distribution of conversational knowledge by the way of discourse (cf. FLUSSER, 1998; FOUCAULT, 1995, p. 170; FLUSSER; WAGNERMAIER; ZIELINSIK, 2009). Another - more universal and not just media-centred - theory-methodological approach would be able to discover (as well) the dialogical potential of communication in a media environment and maybe would meet much closer the emancipative dimension of social media usage in search for social communication.

Yet, the fragmentation of competence of action - even if related to one (commonly shared) process of communication and mutually agreed to be done in an media-technological and media-organized infrastructural environment - into two domains, that of production (providing, acting) and 
that of consumption (usage, reaction) obviously is the practically (and in consequence: the pragmatic) logical conclusion when regarding the technical, organizational and economic conditions as agency (organisational platform) for mediation, medialization or mediatisation (cf. KROTZ, 2008, p. 52) of all kinds of social communication. The political, educational, economic, cultural, or conversational, etc. exchange of news, of information, of knowledge, of experience or of meaning is related to such a technical and organizational complexity and demands such a highly developed ability and capacity of multitasking that can not be managed with sufficient quality of reliability and validity in one (individual) hand. So the principle of outsourcing such capacities and of delegation the authority of acting is the only rational solution. In that sense the affirmative acceptance of the systemic character of social communication has found its peak of expression in Niklas Luhmann's system-theory statement (LUHMANN, 2004, p. 9): "All what we know about our society, even about the world we are living with we know through mass media". Of course, maybe it is needless to say, that in this broad context media are not supposed to be understood just as a socially organized system and not just as a single structural item, but as a structurally organized system of culturally established habits of action and observation (cf. BAUER, 2014, p. 42) - and not just as a technical-cultural environment of communication exchange. A cultural theory of media communication would media never conceptualize by referring to its structures, but rather more by facing its culture of use as well as interpreting it as a social use of culture (cf. BAUER, 2008; 2014; HEPP, 2008; KROTZ, 2008).

\section{Media change: alterations of the interplay of social/societal communication}

Such an axiomatic statement just done, needs to be critically questioned, since particularly it is possible to be stated as such only within a functionalistic perspective of the relation between society and media. In order to overcome the functionalistic mass-perspective of media it makes sense to introduce a linguistic differentiation between mass-media-communication and media-mass-communication. The term mass-media-communication, to what we are generally used so far to use, in practical and theoretical contexts, portrays the social (public) communication as one in itself closed (closable) and completed (result bringing) process between producer-organizations and consumer-masses through media, individually used (consumed) in the 
more or less same manner as any other does - thus being addressed as an agglomeration of consumers, observed as being busy with same or comparable action, through that way becoming an by it's individuals not any more distinguishable and for that an in itself structurally closed and framed mass of mediocrity ( $c f$. LE BON, 1885; ORTEGA Y GASSET, 2002). The mass-perspective in this concept is (and has always been in practical political use especially in all authoritarian systems) an imagination with ideological and functionalist inclusions. That's why the focus of perception lies in media, understanding it as an instrument of influence, manipulation as well as institutional infrastructure for providing masses with information, news, knowledge, entertainment etc. The concept of an obligation of provision of a nation's population with programs of news, education, entertainment etc., as it is even demanded by law (BBC, ORF, ORTF, ARD, ZDF. etc.) only is thinkable with three factors:

- media communication as a dispositive of power and influence, especially dedicated to and useful for public institutions to rule the masses (as to what the population of individuals with divers' concepts of life are finally formed);

- $\quad$ understanding communication as a process of a social agreement of understanding through maximal common codes operated in a process of unification of difference (consensus building / consensual agreement) and distribution of sociality (BAUER, 2006, p. 250);

- and identity building understood as a nationally realizable frame of knowledge and consciousness for all formally nationalized members to be used as a code of reference in order to get identified as "one of us" because being the same like us.

It does not need much force to imagine that this view of usability and fungibility of media for the establishment of societal order, even if this might be considered as a positive function, in its core already includes the inclination of usability of media as a control system. As it reaches masses it also can form masses and can address masses.

The alternative perspective, termed as media-mass-communication portrays in its linguistic constellation social media communication as a connection of symbolic interaction among individually distinguishable masses (social conglomerations of same and comparable interests) using media

- $\quad$ as a model of medium (cf. HEPP, 2008, p. 81); 
- as a platform of distribution of sociability of life, experience, knowledge, and meaning (cf. BAUER, 2014, p. 33);

- $\quad$ as a social network sharing individuality of life, knowledge, etc. (cf. KROTZ, 2008).

Of course, comparing both concepts, the mass-media-communication one and the media-mass-communication one, not only being different in its respect to modern or post-modern perspective, there also had to be considered: there is a difference of perspective between understanding communication and understanding media. While in context of modernity communication is a function of media in the interest of the societal system, in postmodern context, media is the cultural-technical environment of and for conversation. The particular theoretical complexity of mass-media-communication is media- mass-communication - a media organized communication among masses that is overwhelming the horizon of the commonly used management of everyday life - while increasingly interested in and therefor increasingly depending (as well as increasingly depending and therefor increasingly aware of) from news and information coming from the individual's social, cultural, political, economical external environment. Following those interests the system of trust got shifted from a culturally programmed and situationally generated control to a system's organized control, what Habermas (1981, Vol1, p. 533; Vol 2, p. 192) called the colonization of contextual world of living ("Lebenswelt"). Same happened to the cultural tradition of distribution of public trust: the attribution of disposition, ability, capacity, credibility and responsibility (all in all: the concept of competence (BAUER, 2006a, p. 58) got systematized as an organized system of trust (cf. LUHMANN, 1968) in:

- models of economy (success options of quantity, of circulation, of accountability, of effectiveness);

- models of technology (success options of perfection, of minimizing defectiveness, of surprise through simulation of effects, especially of repeatability, of instant-time (dis-synchronicity) and of ubiquity (dystopia));

- models of organization (success options of permanence, of providing equality and even objectivity, of order resp. regularity);

- and in models of professionalization (success options of authority, of delegation of responsibility, and of escape from personal control and of attribution of quality). 
Publicity (Public sphere), objectivity and periodicity are recognized by functionalistic concepts of theory as the pillars of a democratically well-functioning publicist discourse (cf. KLEIN, 2006; MCQUAIL, 2005). It seems that the society, since trying to overcome normative interpretations of life mainly affected by cultural (especially religious) traditions through the project of enlightenment, which might - according to Critical Theory (cf. HORKHEIMER; ADORNO, 1969; 2003) not (yet) be completed, now is challenged to develop such concepts of foundations out of itself through communication on communication. That has to be seen as a way of self-ascertainment, which seemingly is in need of affirmation by means of systemic organization.

When taken communication theoretically not just as the social practice of organizing unity of meaning or opinion in the interest of constructing social order in the model of a hierarchy, but when taking communication theoretically as the challenge of facilitation to get aware of the difference of meaning and opinion in the interest of constructing social order in the model of diversity (cf. BAUER, 2006), then public value emerges as an unavoidable category of rationality of diversity of interpretation of sense of life as well as an unavoidable category of organization of social order of every-day-routine. Social rationality and reasonability (which I understand as an every-day-routine rationality mediated in social comprehension) is the terminological substrate according to the cultural desideratum - and here emerges the connection to the concept of competence - that assumes that humans in connection to the manifold and complex processes of negotiation, to be generated in various contexts and on various levels, raise and put out a set of mind, habit and action (all in all: competence - $c f$. BATESON, 1972) to decide in favour of material and immaterial conditions and resources for a sustainable validity of sense beyond all actually existing boarders because of problems.

This assumption (desideratum) concerns the competence of distinction of the meaning of situations and the decision for sense in mind, habit and action in terms and in interest of benefit (good), aesthetics (image) and ethics (value) (EDMAIR, 1968, p. 63), which is to be translated in respect of conceptualizing media competence: the presumption that any human, under the condition of being free in the usage of media for communication and social connection, is capable and responsible in own interests for the decision for usable goods, for aesthetical images and ethical values within the context of everyday-routine media usage - this assumption is theoretically and culturally 
reasonable and is something that can be alleged and challenged — but has to be educated in the words original meaning: has to be lead through as a socio-political program in frame of a mediality concept of society while being ware of the fact that societies increasingly get constituted in model and code of media (cf. BAUER, 2011a).

The social media movement might bring us back to the roots of situational (out of situation generated use of - and not for other situations made) communication as the original and generative (not reproductive and not reproduced) social practice of constructing and agreeing the reality, and turns around the theoretical look to the relation of media and communication: In context of modernity and its functionalistic theories of mass-mediacommunication many media scientists thought that media make (enable, optimize, maximizes, etc) the communication working in the sense of amplifying effects and potentials of influence (cf. MCQUAIL, 2005). Now in context of postmodern interpretation, understanding the process as media-masscommunication we become aware: communication makes the media working in a sense of using their potentials for fast, instant, situational and eventual communication. In political context this turn-around currently has been shown in many stand-ups of the widely disappointed people. In general terms, this turn-around is the mystery of WikiLeaks: the subversive use of media opens or re-opens opportunities of emancipative communication for whatever that might make sense. The subversive ambition is a conscious connotation of social usage of new (social) media (cf. SCHÄFER, 2008) Not the social media is subversive, but it's use is making media in particular, what it is: a socially shared platform of a conscious emancipation, or at least diffusely intended liberation from the traditional connotation of mass media being in best hands when ruled by institutions and systems of traditional power. Social media consciously will not respect the rituals and rules of mass-media-communication order and not willing to get misused according to the functionalistic concept of society, where media overtake the role as a dispositive of hierarchically structures discourse. Social media use is somehow the antagonist concept to a repressive use of media order (ENZENSBERGER, 1970) and of the occupation power of institutions - thus provoking basis-democratic concepts of dialectic discourse in the model of new mediality of communication. 


\section{Media: a competence-challenge of modern societies}

A cultural and social theory perspective of media communication focuses on the interrelation of observation and action and finds its theoretical paradigm in the concept of signification (cf. HALL, 1989; 1999). Both, observation and action - better to say: observation as an action and action as an observation - construct significations, which get generalized through and as symbolic interaction (cf. MEAD, 1972; HERBERT BLUMER, 1973). The exchange of signification realized in the way of relating action and observation to codes, within a cultural programming development creates generalized configurations of meaning. Culture then is the social interactive and communicative environment to archive those configurations of meaning construction in structures of symbolic and ritual interaction to be used as statement of commitment or as a reference of control for social compliance in case of need. Any style of life is observable as a habitual expression of such commitment and compliance, and that is the reason why it makes sense, when the concept of Cultural Studies observe culture as any "whole way of life" (WILLIAMS, 1958).

The attitude of a communicative habit has to be seen as the cultural basis of a somehow generative competence (ability, capacity, responsibility, motivation) to produce communicatively meant action even in new or unusual contexts of social practice - similar to what Noam Chomsky has conceptualized with the term of a "generative grammar" (CHOMSKY, 1972). On that level all communication systems are addressed by the same general obligation. A society, in which a critical-reflexive usage of communication and media has become an integrative moment of education, is rich in terms of cultural reserves for everyday challenges of a democratic configuration of its social and political development. In that overall context then any specified professional expertise as well gains - at least: functional-credibility.

In such a context media competence is not just the ability, capacity or morality of a reasonable use of media (which is important in relation to media as instruments of communicational connection to the development of society) but is more: is the literacy on the mediality of social and individual life and is the personal awareness that all social relations (expectations as well as fulfilling and evaluation) one is living with are characterized by media-typical values: grade of attention, visibility, publicity, disposability, repeatability etc. Due to the double plural of the term (media) used within everyday practice as well as in scientific theories, and due to special media ontologies 
(LESCHKE, 2007, p. 237) the view to what the medium culturally means has been pushed to the backgrounds: mediality as the symbolic, cultural and social environment and reference of possibility of mutual understanding. The symbolic interaction increasingly refers to a cultural program that has been developed by itself (autopoiesis). Thus, the interaction program continuously replaces through itself, maintaining itself through change by itself. So, not the media change the culture, but culture is changing in the context of the usage of its media as a concrete social practice ( $c f$. Bourdieu's theory of practice: BOURDIEU, 1998; EBRECHT; HILLEBRANDT, 2004) and through its symbolically generated (HILLEBRANDT, 2009) medial substance. The media system explains itself by itself and out of itself what means: nothing can be observed outside of media (LUHMANN; 2004) and nothing whatever we watch is media-free (HARTMANN, 2003). Being aware of this strong and decisive position of media usage within the process of mediatization and medialisation of societal discourse indicates a fundamental need of communication and media literacy as a public value in respect of the societal and democratic value of all kinds of public communication.

The term of literacy is a conceptual statement related to the experience that understanding and using general media structures provides social success but always depends from accessibility to education. So media literacy connects to this concept of literacy and originally in all theoretical frameworks of media education it has been related to the development of personal capacity of accessing to social capital (BOURDIEU, 1982) and always has been seen as a factor of rationality and reasonability within the process of personal socialisation, since it theoretically has been linked to so called cultural techniques of usage of language, to an alphabet or a language code, that is, through reading, writing and understanding and - related to media - especially linked with print media ( $c f$. BAACKE, 1997). However, from there the term literacy has then been extended in order also to cover the skills and competencies involved in finding, selecting, analysing, evaluating and storing information, in its treatment and its use, independently of the codes or techniques involved (STUDY ON MEDIA LITERACY IN EUROPE, 2014). Regarding that the social communication development depends from development of media (media technology) the concept of literacy is more or less a concept for the pragmatic assimilation of educational status to the stages of media-technological development of social (public) communication in terms of codes, structural design, techniques and "generative grammar" (CHOMSKY, 1972, p. 83). So from the point of view of the conceptual development of theory 
media literacy is thought to be a specification of a general set of communicative and cultural competences in order to gain social capital.

In consequence to communication literacy media literacy is a different literacy model and is realized according to Dieter Baacke (1997) at least on four levels:

- media knowledge: know how the system of media is constructed, how it is working - related to technology, economy, politics, law, social values - and under what conditions media fulfil socially useful or as well problematic functions to the society's public discourse;

- media analysis: analyse content, effects, the way and the interest of industrial production of media and understand the position of their potential and power;

- media critiques: value the role of media programmes related to the critical self-observation of the society and to the personal development of knowledge and orientation of life;

- media arrangement: gain ability in social participation through productive media work and learn to express yourself by means of media.

Of course, Baake's concept of media competence is meant as an outcome of media education in a still very instrumental understanding of media and is connected to a functional concept of media as means of power, of influence and of participation. The media-centred understanding of competence made media education becoming a system of learning the media as an instrument for itself. New conceptions of media competence, of course, go farther, but still are quite rare because of the domination of the functional understanding of media. A cultural interpretation of media is much more interested in understanding the meaning (value) of media as a specified and a socialenvironmental indicator of and for a style of communication:

- being in contact, in relation, in mutual attention under conditions of the ever generalized other;

- getting aware and acquainted of each other in relation (and relationability) to technically, organizationally, economically and structurally standardized codes;

- investing trust and credibility to each other through usage of a system of symbols being arranged not in a direct way of construction, but 
in a way of re-using an archive of symbolic structures (symbolically arranged and codified interaction) (BLUMER, 1973; MEAD, 1973; BERGER; LUCKMANN, 1972);

- observing each other not by directly and intrinsically motivated interests, but by supposing the importance and unavoidability of knowing what any other (the generalized other) would know by using the same system of mediation in order to gain information on what is going on to happen and what of that could be a news value for the one and through that also for any other (SCHULZ, 1976; 1990);

- $\quad$ it is the code of news, of eventuality and concernment that characterizes a media organized communication and that relates people to each other in a more or less standardized (in terms of distributive media) and a more or less pre-designed (in terms of net and social media) way of interrelation, inter-observation and interaction.

To come along with this code of mediality in a way to keep the balance between assimilation to social, cultural and symbolic environment and accommodation of social, cultural and symbolic environment (cf. PIAGET, 1947) what means the intelligent balance between the code of media and the code of culture of authentic, meaningful and mindful life demands a rationality and reasonability, which has to be learned in order to train the functional memory of individuals and the cultural one of society ( $c f$. BATESON, 1972). The fear not to get lost in the code of media has to be combined with the ambition to find one's autonomy in and through communication. Not to get lost in generalized standards or superficial design, not to get dispersed, dissolved or dissipated in news, not to get lost in simulation or in cyberspace and not to get alienated from one's own code of interest and building a concept of identity and idiosyncrasy (KAMPER, 1999) exactly in that way of getting aware of being related to any generalized other (KRAPPMANN, 2000; HABERMAS, 1973) is the feat of media competence and media literacy.

Thomas A. Bauer is professor in the Department of Communication of University of Vienna, Austria. His research is in media culture, media education, media literacy studies, social, cultural and media change, transcultural communication, interreligious dialogue, media philosophy, media theory, and epistemology for social sciences. He has published several books and articles both in Austria and abroad. 


\section{References}

ADORNO, T. W. Ästhetische Theorie. Frankfurt: Suhrkamp, 1970.

BAACKE, D. Medienkompetenz. Tübingen: Niemeyer Verlag, 1997.

BATESON, G. A theory of play. Steps to an ecology of mind. London: Intertext, 1972, p. 177-193.

BAUER, T. A. Culture of diversity: a theoretical concept towards transcultural understanding. In: BAUER, T. A.; ORTNER, G. E. (Eds). Werte für Europa: Medienkultur und ethische Bildung in und für Europa. Düsseldorf: B\&B Vlg, 2006, p. 242-267.

Kommunikationskulturen im Wandel: Wertemodelle und Wissensmodelle der Mediengesellschaft. In: BAUER, T. A.; ORTNER, G. E. (eds.): Werte für Europa: Medienkultur und ethische Bildung in und für Europa. Düsseldorf: B\&B Vlg, 2006a, p. 48-62.

. Signaturen der Mediengesellschaft: Stilbildung und Ästhetik des Lebens in Fluidum von Medialität. In: BAUER, T. A. / ORTNER, G. E. (eds.): Bildung für Europa: politische Ansprüche und Anregungen für die Praxis. Paderborn: B+B, 2008, p.122-145.

Public value: media literacy. In: CHRISTL, R.; SÜSSENBACHER, D. (eds). Der öffentlich-rechtliche Rundfunk in Europa: ORF, BBC, ARD \& Co auf der suche nach dem Public Value. Wien: Falter Verlag, 2010.

Verstehen und beobachten: ein plädoyer für eine trans-kommunikative Methodologie der Sozialwissenschaft. Politix 29/2011: Zeitschrift des Instituts für Politikwissenschaft an der Universität Wien, 2011, p. 20-24.

BAUER, T. A. In Zukunft mehr Kommunikation: Gesellschaft im Spiegel des Medienwandels. In: KOSCHNIK, W. J. (ed.). Focus Jahrbuch 2010, S. 1-83, 2011 a.

Kommunikation wissenschaftlich denken: perspektiven einer kontextuellen theorie gesellschaftlicher Verständigung. Wien: Böhlau, 2014.

BECKER, D. (ed.). Einführung in die Systemtheorie: Niklas Luhmann. Heidelberg: Carl Auer, 2005.

BERGER, P. L.; LUCKMANN, T. Die gesellschaftliche Konstruktion von Wirklichkeit: eine Theorie der Wissenssoziologie. Frankfurt: a. M., 1972.

BLUMER, H. Der methodologische Standpunkt des symbolischen Interaktionismus. In: Arbeitsgruppe Bielefelder (Hrsg.): alltagswissen, Interaktion und gesellschaftliche Wirklichkeit. Bd 1: Symbolischer Interaktionismus uns Ethnomethodologie. Reinbeck: Rowohlt, 1973, p. 80-101.

BOURDIEU, P. Die feinen Unterschiede. Frankfurt: Suhrkamp, 1982.

Praktische Vernunft: zur Theorie des Handelns. Frankfurt: Suhrkamp, 1998.

BURS, G. M. Kontext: Sinnstiftung in virtuellen Systemen. Weilerwist: Velbrück, 2019. 
CHOMSKY, N. Aspekte der syntax-theorie. Frankfurt: Suhrkamp, 1972.

EBRECHT, J.; HILLEBRANDT, F. (eds). Bourdieus Theorie der Praxis: Erklärungskraft, Anwendung, perspektiven. Wiesbaden: Verlag für Sozialwissenschaften ( $2^{\circ}$ Edition), 2004.

EDMAIR, A. Horizonte der Hoffnung: eine philosophische studie. Regensburg: Pustet, 1968.

ENZENSBERGER, H. M. Baukasten zu einer Theorie der Medien. Kursbuch 20. Frankfurt: Suhrkamp, 1970, p. 159-186.

FLUSSER, V. Kommunikologie. Hrsg. Von Stefan Bollmann und Edith Flusser. Frankfurt/M.: Fischer, 1998.

FLUSSER, V.; WAGNERMAIER, S.; ZIELINSKI, S. Kommunikologie weiterdenken: die Bochumer Vorlesungen. Frankfurt (Fischer), 2009.

FOUCAULT, M. Die Ordnung der dinge: eine archäologie der humanwissenschaften. Frankfurt: Suhrkamp, 1974.

. Archäologie des Wissens. Frankfurt: Suhrkamp (7 Ed.), 1995.

GADAMER, H-G. Wahrheit und Methode: Grundzüge einer philosophischen Hermeneutik. Tübingen: Mohr, 1972.

GASSET, J. O. Der Aufstand der Massen. Wiesbaden: dva, 2002.

HABERMAS, J. Vorbereitende Bemerkungen zu einer Theorie der kommunikativen Kompetenz. In: HABERMAS, J.; LUHMANN, N.: Theorie der Gesellschaft oder Sozialtechnologie: was leistet die Systemforschung? Frankfurt, 1971, 101-141.

. Notizen zum Begriff der Rollenkompetenz. In: Kultur und Kritik: Verstreute Aufsätze. Franfkurt: Suhrkamp, 1973, p. 198-232.

. Theorie des kommunikativen Handelns. Bd 1: Handlungsrealität und gesellschaftliche Rationalisierung. Frankfurt: Suhrkamp; Handlungsrationalität und gesellschaftliche Rationalisierung.

Theorie des kommunikativen Handelns: Bd 2: Kritik der funktionalistischen Vernunft. Frankfurt: Suhrkamp, 1981. Frankfurt: Suhrkamp; Handlungsrationalität und gesellschaftliche Rationalisierung.

HALL, S. Cultural Studies. Two Paradigms. Media, Culture, and Society Nr. 1. New York, 1980, p. 57-72.

Ideologie, Kultur, Medien, Neue Rechte, Rassismus. Hamburg: Argument, 1989.

. Encoding. Decoding. In: DURING, S. (ed.). The Cultural Studies Reader. London: Routledge, 1999, p. 507-517.

HARTMANN, F. Mediologie: Ansätze einer Medientheorie der Kulturwissenschaften. Wien: Facultas, 2003. 
HEPP, A. Netzwerke der Medien: Medienkulturen und Globalisierung. Wiesbaden: VS Verlag für Sozialwissenschaften, 2004.

. Netzwerke der Medien: Netzwerke des Alltags: Medienalltag in der Netzwerkgesellschaft. In: THOMAS, T. (ed): Medienkultur und soziales Handeln. Wiesbaden: Verlag für Sozialwissenschaften, 2008, p. 63-89.

. Medienkultur: Die Kultur mediatisierter Welten. Wiesbaden: VS Verlag für Sozialwissenschaften, 2011.

HILLEBRANDT, F. Praktiken des Tauschens: Zur Soziologie symbolischer Formen der Reziprozität. Wiesbaden: erlag für Sozialwissenschaften, 2007.

HORKHEIMER, M.; ADORNO, T. W. Dialektik der Aufklärung: Philosophische Fragmente. Frankfurt: Fischer Verlag, [1969] 2003.

KAMPER, D. Idiosynkrasien ed. by Paragrana. Interdisziplinäres Zentrum für Historische Anthropologie Vol. 8/ 2, Freie Universität Berlin. Ed. by Dietmar Kamper; Bernd Ternes. Berlin: Akad. Verlag, 1999.

KLEIN, P. Henk Prakke und die funktionale Publizistik: Über die Entgrenzung der Publizistik- zur Kommunikationswissenschaft. Berlin: LIT Verlag, 2006.

KRAPPMANN, L. Soziologische Dimensionen der Identität: strukturelle Bedingungen für die Teilnahme an Interaktionsprozessen. Stuttgart: Klett-Cotta Verlag, 2000.

KROTZ, F. Mediatisierung von Alltag, Kultur und Gesellschaft: Ein gesellschaftlicher Metaprozess wird besichtigt. Wiesbaden: Verlag für Sozialwissenschaften, 2001.

. Kultureller und gesellschaftlicher Wandel im Kontext des Wandels von Medien und Kommunikation. In: THOMAS, T. (ed.). Medienkultur und soziales Handeln. Wiesbaden: Verlag für Sozialwissenschaften, 2008, p. 43-62.

KURT, R. Hermeneutik: Eine sozialwissenschaftliche Einführung. Konstanz: UVK, 2004.

LE BON, G. Psychologie der Massen. Stuttgart: Kröner, 1982.

LESCHKE, R. Einführung in die Medientheorie. München: Fink, 2007.

LUHMANN, N. Vertrauen: Ein Mechanismus der Reduktion sozialer Komplexität. Stuttgart: Verlag, 1968.

Soziale Systeme: Grundriss einer allgemeinen Theorie. Frankfurt: Suhrkamp, 1984.

Die Realität der Massenmedien. Wiesbaden: Verlag für Sozialwissenschaften (3. Auflage), 2004.

MCQUAIL, D. Mass Communication Theory. (5th edition). London: Sage Publication, 2005.

MEAD, G. H. Geist, Identität und Gesellschaft. Frankfurt: Suhrkamp, 1934/ 1973. 
PIAGET, J. La représentation du monde chez l'enfant. Paris: PUF, 1947.

SCHÄFER, M. T. Bastard Culture! How User Participation Transformes Cultural Production. Utrecht: University Press, 2008.

SCHMIDT, S. J. Geschichten \& Diskurse: Abschied vom Konstruktivismus. Reinbeck: Rowohlt, 2003.

SCHÜTZ, A.; LUCKMANN, T. Strukturen der Lebenswelt. Konstanz: UVK, 2003.

SCHULZ, W. Die Konstruktion von Realität in den Nachrichtenmedien. Freiburg, München: Carl Alber (2nd ed.), 1990.

STUDY ON MEDIA LITERACY. Current Trends and Approaches to Media Literacy in Europe, 2014. Available: <http://ec.europa.eu/culture/media/literacy/docs/studies/study. pdf>. Access: Aug. 3, 2020.

WEBER, S. Doppelte Differenz: Schritte zu einer, konstruktivistischen Systemtheorie der Medienkommunikation. In: Medien Journal 1/1997 Salzburg-Wien, 1997, S. 34-43.

WILLIAMS, R. Culture and Society, 1780-1950. London: Chatto \& Windus, 1958.

Ensaio recebido em 06/09/2020 e aprovado em 20/11/2020. 